\title{
ASPECTS OF LATE DEVONIAN AND EARLY CARBONIFEROUS PALYNOLOGY OF SOUTHERN IRELAND. II. THE AURORASPORA MACRA MORPHON
}

\author{
C.J. VAN DER ZWAN \\ Laboratory of Palaeobotany and Palynology, State University, Utrecht (The Netherlands)
}

(Received and accepted January 29, 1979)

\begin{abstract}
Van der Zwan, C.J., 1980. Aspects of Late Devonian and Early Carboniferous palynology of southern Ireland. II. The Auroraspora macra morphon. Rev. Palaeobot. Palynol., 30: $133-155$.
\end{abstract}

The continuous variation in a group of Late Devonian-Early Carboniferous camerate spores from southern Ireland, assigned to species of Auroraspora, Colatisporites and Endoculeospora can be denoted by recognizing the Auroraspora macra morphon. This non-typological unit is introduced by discussing: (1) the taxonomy of the constituent species [Auroraspora macra Sullivan 1968, A. hyalina (Naumova) Streel in Becker et al. 1974, A. asperella (Kedo) nov. comb. Van der Zwan, Colatisporites decorus (Bharadwaj et Venkatachala) Williams in Neves et al. 1973, and Endoculeospora gradzinskii Turnau $1975] ;(2)$ the continuous morphological variation; and (3) the biostratigraphical application, as well as the related form Auroraspora rectiformis (Naumova) nov. comb. Van der Zwan.

\section{INTRODUCTION}

Classification of Late Devonian-Early Carboniferous spores is frequently hampered by the continuous morphological variation, transgressing the artificial demarcation between different form genera and/or species. Investigations concerning Late Devonian-Early Carboniferous palynological assemblages from southern Ireland, have earlier resulted in a publication (Van der Zwan, 1979) in which the morphological morphon concept was introduced, exemplified by the Cyrtospora cristifer morphon, as an aid to the classification of spores showing continuous variation in morphological characteristics.

In the present paper this concept has been applied to a group of camerate spores with spongeous outer walls and a few other common diagnostic features; viz. Auroraspora macra Sullivan 1968, A. hyalina (Naumova) Streel in Becker et al. 1974, A. asperella (Kedo) nov. comb. Van der Zwan, Colatisporites decorus (Bharadwaj et Venkatachala) Williams in Neves et al. 1973, and Endoculeospora gradzinskii Turnau 1975. 


\section{DESCRIPTIVE PALYNOLOGY}

Form genus: Auroraspora Hoffmeister, Staplin et Malloy 1955

Type species: Auroraspora solisorta Hoffmeister, Staplin et Malloy 1955

Remarks: In the original diagnosis by Hoffmeister et al. (1955) the type species is said to have a finely granulose bladder, this addition was left out in the emended diagnosis by Richardson (1960). As most specimens here studied bear some scattered small grana, the original diagnosis is here preferred.

\section{Species: Auroraspora macra Sullivan 1968}

Holotype: Auroraspora macra Sullivan 1968, plate 27, fig.7.

Figured specimens: Plate I, 2, 4, 6 .

Identifying characters: Overall and inner body outlines subtriangular with convex sides to subcircular. Ratio of diameter inner body to total spore diameter about $3 / 4(2 / 3-4 / 5)$. Wall inner body smooth or scabrate, $1-2 \mu \mathrm{m}$ in thickness. Outer wall with more or less distinct spongeous infrastructure; surface frequently bearing scattered grana up to $0.5 \mu \mathrm{m}$ in diameter; thickness indistinct, when measurable up to $1.5 \mu \mathrm{m}$. In the equatorial area the outer wall is usually folded. Trilete rays indistinct or distinct, simple or labrate, labra up to $3 \mu \mathrm{m}$ in width, length $2 / 3-1 / 1$ of inner body radius.

Observed dimensions: total spore diameter 40-(48)-80 $\mu \mathrm{m}$; diameter inner body 30-(36)-60 $\mu \mathrm{m}$.

Remarks: The specimens found in the Bantry Bay material are in agreement with the diagnosis of Auroraspora macra Sullivan 1968; within the variation found in the species, many specimens occur with a mainly rounded triangular outline and also with trilete rays with a length equal to the radius of the inner body. In this case the specimens are comparable with Auroraspora minuta Richardson 1964, as described from the Middle Devonian of Scotland. Since specimens with trilete rays with a length of $2 / 3$ of the inner body radius are more abundant, and since $A$. macra is an essentially Early Carboniferous species, an assignment to $A$. macra is preferred.

The species is differentiated from Endosporites pallidus Schemel 1950 by its distinct infrastructure and generally distinct trilete rays. It is differentiated from Endosporites minutus Hoffmeister, Staplin et Malloy 1955 by its distinct infrastructure and by the absence of radial folds. The specimens described as Endosporites cf. minutus in Combaz and Streel (1970) and in Streel (1966) have been assigned to Auroraspora hyalina in Clayton et al. (1977), but according to the present author these forms are conspecific with $A$. macra, even though laevigate forms are not represented in the Bantry Bay material. Endosporites sp.2947 in Lanzoni and Magloire (1969) is probably also assignable to A. macra. A. macra can be distinguished from Hymenozonotriletes commutatus Naumova 1953 by a higher ratio of the diameter inner body to total spore diameter, by the absence of a perine, by the absence of radial folds and by the frequently more subtriangular outline. 
Species: Auroraspora hyalina (Naumova) Streel in Becker et al. 1974

\section{3: Hymenozonotriletes hyalinus Naumova}

Holotype: Hymenozonotriletes hyalinus Naumova 1953, prep. no.3450/3444; illustration not indicated; here plate 17, fig.15 of Naumova (1953) is considered to represent the holotype.

Figured specimens: Plate I, 3, 5 .

Identifying characters: Overall outline and outline inner body subtriangular with convex sides to subcircular, outline inner body occasionally more subtriangular than the outline of the outer body. Ratio of diameter inner body to total spore diameter about $2 / 3(1 / 2-3 / 4)$. Wall inner body smooth or scabrate, $1-2 \mu \mathrm{m}$ in thickness. Outer wall with more or less distinct spongeous infrastructure; surface occasionally ornamented with scattered grana, up to $1 \mu \mathrm{m}$ in diameter. In the equatorial region the outer wall is often folded, the thickness is indeterminable. Trilete rays indistinct or distinct, simple or labrate, in length equal to inner body radius; labra up to $3 \mu \mathrm{m}$ in width. The exine parallel to the rays is sometimes thickened.

Observed dimensions: Total spore diameter in the Bantry Bay material 25(36)-47 $\mu \mathrm{m}$, in the Hook Head material up to $50 \mu \mathrm{m}$; diameter inner body in Bantry Bay and in Hook Head 15-(23)-32 $\mu \mathrm{m}$.

Remarks: The species can be distinguished from Endosporites parvus Staplin 1960 by the longer trilete rays of the latter species (in length equal to the total radius of the spores). Hymenozonotriletes hyalinus in Caro-Moniez (1962) might well be assigned to $E$. parvus rather than to A. hyalina. The species is differentiated from Hymenozonotriletes commutatus Naumova 1953 by the absence of a perine and radial folds.

According to Clayton et al. (1977), Endosporites cf. minutus Hoffmeister, Staplin et Malloy 1955 as recorded in Combaz and Streel (1970) and Streel (1966) and perhaps Endosporites sp.2947 in Lanzoni and Magloire (1969) are conspecific with $A$. hyalina; it is here considered, however, that the morphology of the figured specimens is more comparable with the description as given for $A$. macra.

Species: Auroraspora rectiformis (Naumova) nov. comb. Van der Zwan Basionym: Hymenozonotriletes rectiformis Naumova 1953, Trans. Inst. Geol. Sci., Acad. Sci. U.S.S.R., Rel.143, Geol. Ser. No.60: 114, plate 17, fig.20.

Holotype: Hymenozonotriletes rectiformis Naumova 1953, plate 17, fig. 20 . Figured specimens: Plate I, 1.

Identifying characters: Overall outline and outline inner body subtriangular with slightly convex sides. Ratio diameter inner body to total spore diameter about 5/6. Wall inner body smooth, 1-2 $\mu \mathrm{m}$ in thickness. Outer wall smooth or finely infrapunctate, thin, sometimes loosely folded in the equatorial region. Trilete rays distinct, simple or labrate, or partly labrate, in length equal to inner body radius; labra up to $1 \mu \mathrm{m}$ in width. The exine parallel to the rays is sometimes thickened, thickenings up to $2 \mu \mathrm{m}$ in width. 


\section{PLATE I}
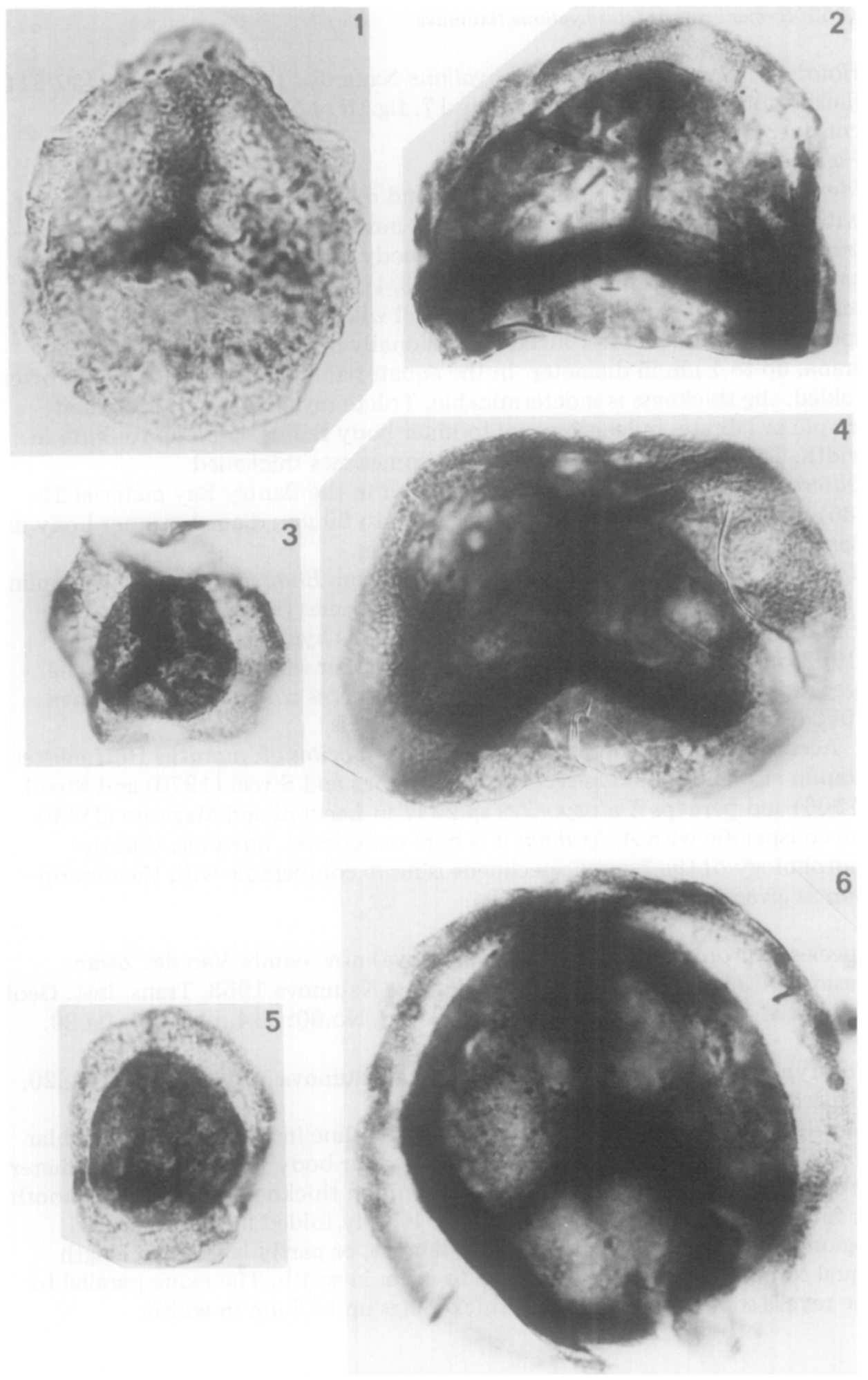
Observed dimensions: total spore diameter 24-(38)-55 $\mu \mathrm{m}$, diameter inner body 23-(31)-45 $\mu \mathrm{m}$.

Remarks: Since all characters are fully in agreement with Auroraspora, the present species has been transferred into this form genus.

The species is differentiated from A. asperella (Kedo) nov. comb. Van der Zwan by the absence of ornamentation.

Species: Auroraspora asperella (Kedo) nov. comb. Van der Zwan

Basionym: Archaeozonotriletes asperellus Kedo 1974 in Golubtsov, V.K. and Manjkin, S.S. (Editors), Paleozoic Spores of Byelorussia (Pripyat Valley), p.55, plate 13 , fig. 12 .

Holotype: Archaeozonotriletes asperellus Kedo 1974, plate 13, fig.12.

The species is here transferred to Auroraspora to accommodate in a broad sense small camerate spores with a variable ornamentation of small grana. Within this concept three variants can be recognized which will be treated separately hereafter.

Variant: Auroraspora asperella variant A

Figured specimens: Plate II, 1-7; III, 1.

Identifying characters: Overall outline and outline inner body subtriangular with convex sides. Ratio of diameter inner body to total spore diameter about 9/10. Wall inner body smooth, $1-1.5 \mu \mathrm{m}$ in thickness. Outer wall with spongeous infrastructure, thin, frequently folded. Surface ornamented with minute grana, up to $0.5 \mu \mathrm{m}$ in width and at least $1 \mu \mathrm{m}$ apart; distal ornamentation more prominent than proximal ornamentation. Trilete rays, indistinct or distinct, simple or labrate, length $1 / 2-1 / 1$ of inner body radius. Labra up to $3 \mu \mathrm{m}$ in width, they may diverge towards the apices.

Observed dimensions: Total spore diameter 18-(27)-37 $\mu \mathrm{m}$, diameter inner body 16-(23)-35 $\mu \mathrm{m}$.

Remarks: Archaeozonotriletes luteolus Naumova 1953 (= Hymenozonotriletes luteolus of Kedo, 1957 = Perotriletes luteolus of Von Almen, 1970) is quite comparable with variant $\mathrm{A}$, but according to the diagnosis the exine seems to be more densely ornamented. Further investigations might, however, prove that $A$. asperella has to be regarded as a junior synonym of Archaeozonotriletes luteolus.

Another similar species may be Hymenozonotriletes subgranulatus Naumova in Kedo 1963, but also for this taxon the diagnosis is still too incomplete to ascertain identification.

PLATE I (approx. $\times$ 900)

1. Auroraspora rectiformis (Naumova) nov. comb. Van der Zwan.

2, 4, 6. Auroraspora macra Sullivan 1968.

3, 5. Auroraspora hyalina (Naumova) Streel in Becker et al. 1974. 


\section{PLATE II}
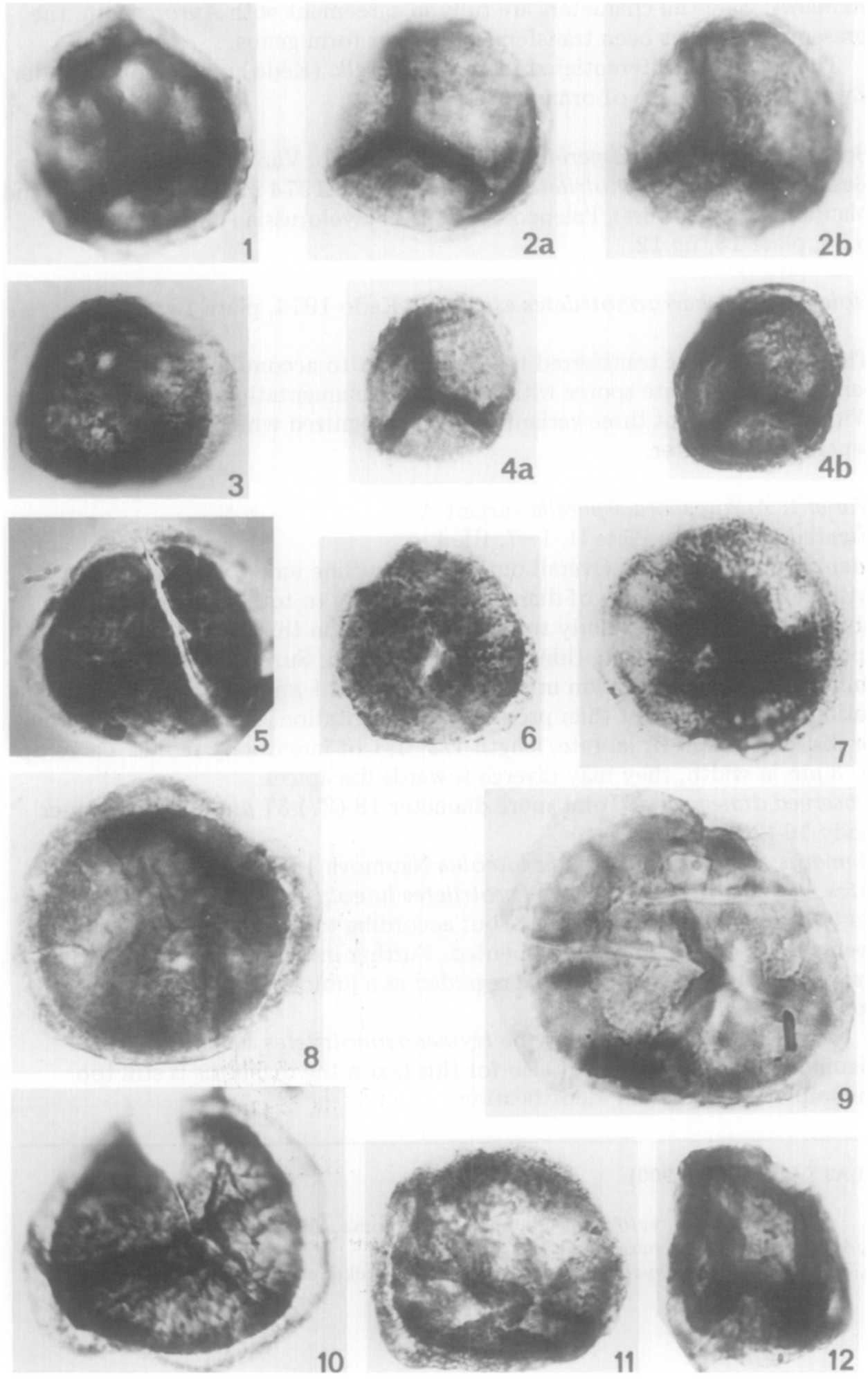
Variant A is differentiated from variant $B$ (see below) by its subtriangular outline and its frequently smaller size; it is differentiated from variant $\mathrm{C}$ by the absence of well-developed labra. Variant $A$ is distinguished from subtriangular forms of Colatisporites decorus (p. 141) by its smaller size and its denser ornamentation. It is differentiated from Auroraspora rectiformis by the presence of ornamentation.

\section{Variant: Auroraspora asperella variant B}

Figured specimens: Plate II, 8-11; III, 2.

Identifying characters: Overall outline and outline inner body rounded triangular with convex sides to subcircular. Ratio of diameter inner body to total spore diameter about 4/5 (2/3-9/10). Wall inner body smooth or scabrate, sometimes folded, thickness 1-1.5 $\mu \mathrm{m}$. Outer wall with fine spongeous infrastructure, thickness when measurable up to $1 \mu \mathrm{m}$. Surface proximally and distally ornamented with grana up to $1 \mu \mathrm{m}$ in width and up to $0.5 \mu \mathrm{m}$ in height; ornamentation especially prominent on the distal face above the inner body. Trilete rays indistinct or distinct, simple or labrate or partly labrate, length $2 / 3-1 / 1$ of inner body radius. Labra up to $3 \mu \mathrm{m}$ in width.

Observed dimensions: Total spore diameter 24-(33)-40 $\mu \mathrm{m}$; diameter inner body 20-(26)-34 $\mu \mathrm{m}$.

Remarks: Variant B may be rather comparable with Hymenozonotriletes sub. granulatus Naumova in Kedo 1963, but the diagnosis is too incomplete to be sure. Auroraspora granulipunctata (Hoffmeister, Staplin et Malloy) Turnau 1975 is differentiated from this variant by its radial folds. Hymenozonotriletes luteolus as identified by Combaz and Streel (1970) is probably identical with this variant.

The variant shows continuous variation with $A$. macra, A. hyalina, $A$. asperella variant $\mathrm{A}$ and Colatisporites decorus, it can be differentiated from these species by its characteristic ratio diameter of inner body to total spore diameter, size and outline. It can be differentiated from $A$. rectiformis by the presence of ornamentation.

\section{Variant: Auroraspora asperella variant $\mathrm{C}$}

Figured specimens: Plate II, 12.

Identifying characters: Overall outline and outline inner body subtriangular with convex sides. Ratio of diameter inner body to total spore diameter $3 / 4-9 / 10$. Wall inner body smooth or scabrate, up to $1 \mu \mathrm{m}$ in thickness. Outer wall with fine spongeous infrastructure, frequently folded in the

PLATE II (approx. $\times$ 900)

Auroraspora asperella (Kedo) nov. comb. Van der Zwan

1-7. Variant A (1: equatorial view; 2a, b: proximal and distal view; 4a, b: proximal and equatorial view).

8-11. Variant B.

12. Variant C. 


\section{PLATE III}
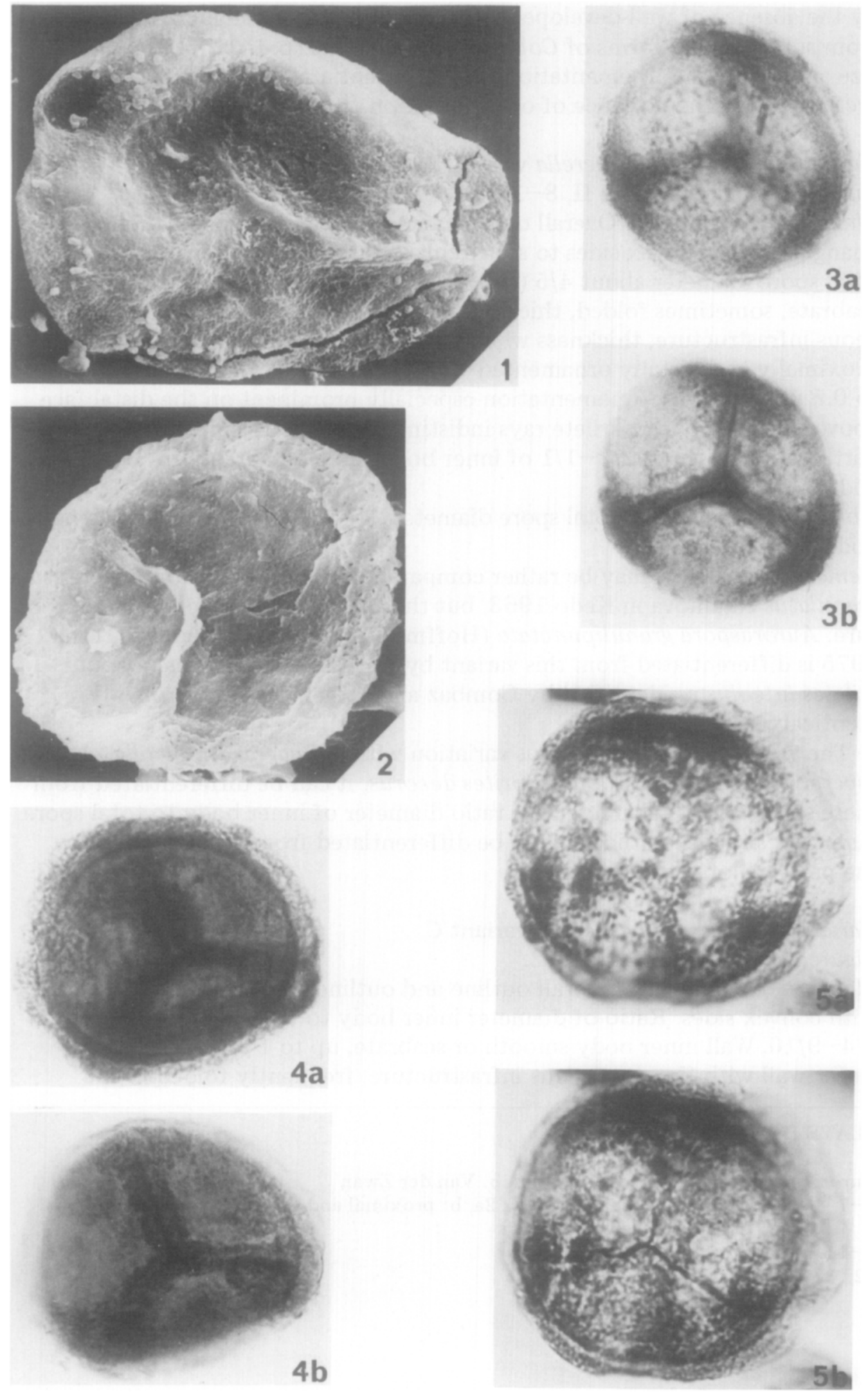
equatorial region. Surface proximally and distally ornamented with minute grana, up to $0.5 \mu \mathrm{m}$ in width. Trilete rays distinct, labrate, length equal to inner body radius. Labra sinuous, bulbous, often widening towards the inner body outline, sometimes reaching the equator, $2-4 \mu \mathrm{m}$ in width.

Observed dimensions: Total spore diameter 22-(27)-35 $\mu \mathrm{m}$; diameter inner body 18-(22)-30 $\mu \mathrm{m}$.

Remarks: The species is highly comparable with variant $\mathrm{A}$, it is distinguished on the basis of its well-developed labra. Hymenozonotriletes punctatus var. minor Kedo 1963 has comparable labra, but is distinctly subcircular.

Form genus: Colatisporites Williams in Neves et al. 1973

Type species: Colatisporites decorus (Bharadwaj et Venkatachala) Williams in Neves et al. 1973

Remarks: Williams (in Neves et al., 1973) did not classify the form genus above the generic level, as in his opinion the attachment of the two exinal layers was not clear; the present author classifies this form genus as camerate on the basis of the distinctive exinal differentiation, in which an inner and an outer layer may be recognized.

Species: Colatisporites decorus (Bharadwaj et Venkatachala) Williams in Neves et al. 1973

Holotype: Tholisporites decorus Bharadwaj et Venkatachala 1961, plate 10, fig.142

Based on the material examined, the species is divided into two variants.

Variant: Colatisporites decorus variant A

Figured specimens: Plate III, 3-5; IV, 1-3.

Identifying characters: Overall outline and outline inner body subcircular, elliptical or subtriangular with convex sides. Ratio of diameter inner body to total spore diameter about $9 / 10$. Wall inner body smooth or scabrate, thin, occasionally folded parallel to the inner body outline. Outer wall with distinct spongeous infrastructure, frequently wrinkled, smooth or ornamented with scattered small grana, $0.5 \mu \mathrm{m}$ in width. Trilete rays indistinct or distinct, simple or labrate or partly labrate, length $2 / 3-1 / 1$ of inner body radius. Labra up to $3 \mu \mathrm{m}$ in width. Radial region sometimes accentuated by folds resembling curvaturae imperfectae.

PLATE III

1, 2. Auroraspora asperella (Kedo) nov. comb. Van der Zwan (scanning micrographs, approx. X 2000; 1: variant A; 2: variant B).

3-5. Colatisporites decorus (Bharad waj et Venkatachala) Williams in Neves et al. 1973 variant $A$ (approx. $\times 900 ; 3 a, b, 4 a, b, 5 a, b$ : distal and proximal view; 5 : specimen transitional to Auroraspora asperella variant B). 


\section{PLATE IV}
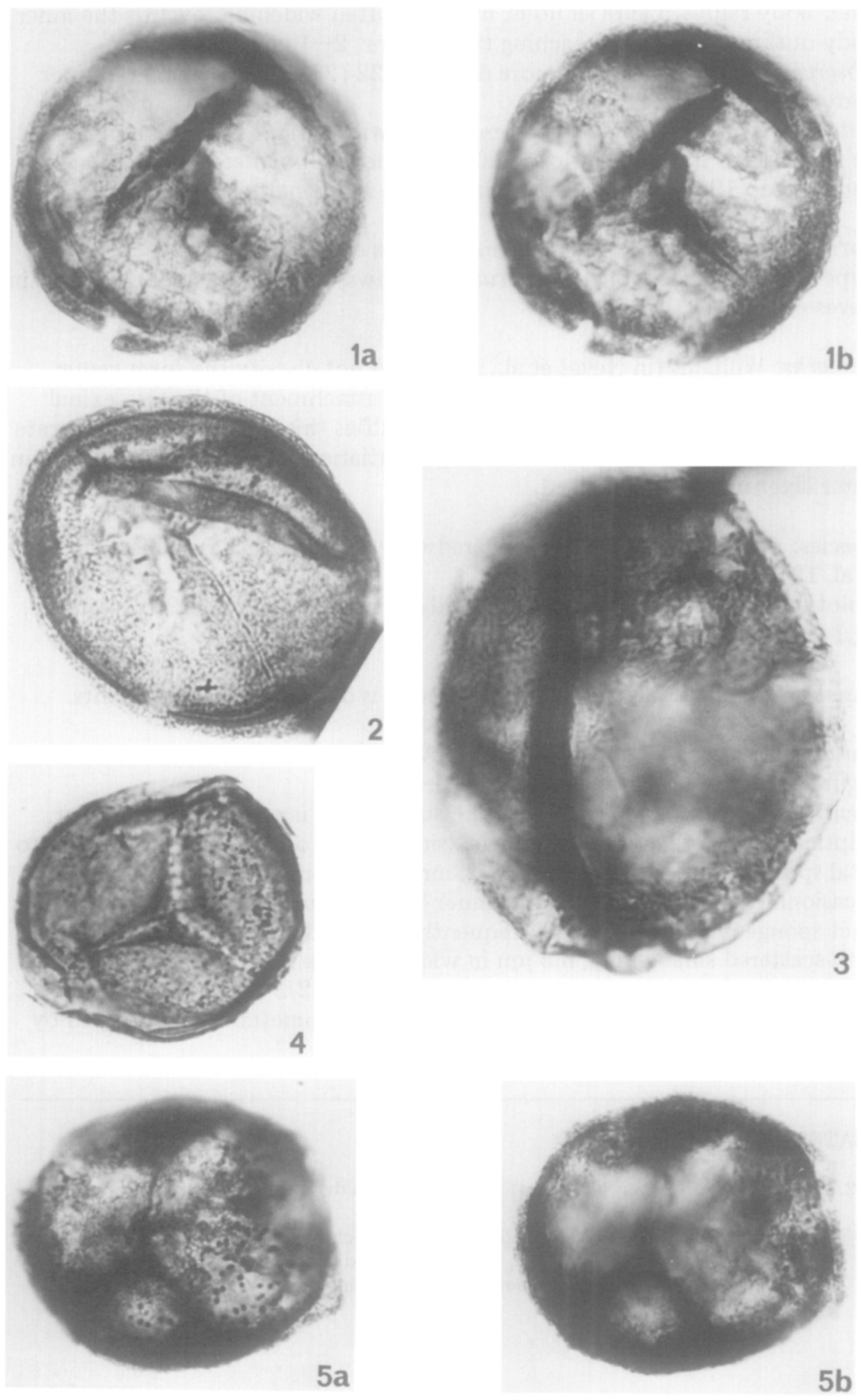
Observed dimensions: Total spore diameter Bantry Bay material, both elliptical and subtriangular specimens 22-(38)-55 $\mu \mathrm{m}$; in Garryvoe $47-75 \mu \mathrm{m}$; diameter inner body in Bantry Bay 18-(34)-53 $\mu \mathrm{m}$; in Garryvoe 40-65 $\mu \mathrm{m}$. Remarks: Within the material the specimens are either subcircular to elliptical or they are distinctly subtriangular, since in both categories the size and the other characters are fully in agreement with each other no taxonomic distinction has been made.

Most of the specimens observed show the presence of scattered small grana. This feature is here considered of little diagnostic value and an assignment to Colatisporites decorus seems justified. The differentiation from $A$. asperella variant $A$ and variant $B$ has already been discussed (p. 139).

$A$. rectiformis may be distinguished on the basis of its lower ratio of diameter inner body to total spore diameter and its finer infrastructure.

\section{Variant: Colatisporites decorus variant B}

Figured specimens: Plate IV, 4, 5 .

Identifying characters: Overall outline and outline inner body subcircular to elliptical, occasionally subtriangular with convex sides. Ratio of diameter inner body to total spore diameter about $9 / 10$. Wall inner body scabrate, thin, frequently folded parallel to the inner body outline. Outer wall with distinct spongeous infrastructure. Surface equatorially and distally ornamented with minute bacula and clavae, up to $2 \mu \mathrm{m}$ in height and less than $0.5 \mu \mathrm{m}$ in width; at least $1 \mu \mathrm{m}$, usually more than $3 \mu \mathrm{m}$ apart. Contact area devoid of ornamentation, occasionally accentuated by folds, resembling curvaturae imperfectae. Trilete rays distinct, simple or labrate, in length $2 / 3-1 / 1$ of inner body radius. Labra thin up to $2 \mu \mathrm{m}$ in width.

Observed dimensions: Total spore diameter in Bantry Bay 40-(45)-53 $\mu \mathrm{m}$, in Hook Head 35-67 $\mu \mathrm{m}$; diameter inner body in Bantry Bay 36-(40)-50 $\mu \mathrm{m}$, in Hook Head 29-64 $\mu \mathrm{m}$.

Remarks: Variant B is morphologically intermediate between C. decorus variant A and $C$. denticulatus Neville in Neves et al. 1973 as the ornamentation is much more scattered than in $C$. denticulatus, but still baculate in comparison with the granulate specimens of $C$. decorus variant $A$. The variant can be differentiated from Endoculeospora gradzinskii variant A and variant B (p.144) on the basis of its more subcircular outline, its higher ratio of diameter inner body to total spore diameter, its thinner labra, and on the occasional presence of curvaturae imperfectae.

Form genus: Endoculeospora (Staplin) emend. Turnau 1975 Type species: Endoculeospora rarigranulata Staplin 1960

PLATE IV (approx. $\times$ 900)

Colatisporites decorus (Bharadwaj et Venkatachala) Williams in Neves et al. 1973

1-3. Variant A (1a, b: distal and proximal view; 2, 3: elliptical forms).

4, 5. Variant $\mathrm{B}$ ( $5 \mathrm{a}, \mathrm{b}$ : distal and proximal view). 
Species: Endoculeospora gradzinskii Turnau 1975

Holotype: Endoculeospora gradzinskii Turnau 1975, plate 7, fig.1.

Based on the material examined the species is divided into two variants.

Variant: Endoculeospora gradzinskii variant A

Figured specimens: Plate V, 1, 2.

Identifying characters: Overall outline and outline inner body usually sub-

triangular with convex sides, occasionally subcircular. Ratio of diameter inner body to total spore diameter about 4/5 (2/3-9/10). Wall inner body smooth, thin, occasionally up to $2 \mu \mathrm{m}$ in width. Outer wall with indistinct spongeous infrastructure, ornamented equatorially and distally with small bacula, clavae and to a minor degree spinae or grana, $0.5-1.5 \mu \mathrm{m}$ in height, normally less than $0.5 \mu \mathrm{m}$ in width, occasionally up to $1 \mu \mathrm{m}$; loosely set, $0.5-4 \mu \mathrm{m}$ apart. Trilete rays indistinct or distinct, simple or labrate, length $2 / 3-1 / 1$ of inner body radius. Labra up to $3 \mu \mathrm{m}$ in width, sometimes diverging towards the equator.

Observed dimensions: Total spore diameter 25-(30)-35 $\mu \mathrm{m}$, diameter inner body 20-(25)-30 $\mu \mathrm{m}$.

Remarks: Variant A is differentiated from variant B by its smaller size and by the slenderness of its ornamentation. Variant $A$ is differentiated from Colatisporites decorus variant $\mathrm{B}$ by its subtriangular outline and by its finer infrastructure.

\section{Variant: Endoculeospora gradzinskii variant B}

Figured specimens: Plate V, 3-5; VI, 1-4.

Identifying characters: Overall outline and outline inner body usually subtriangular with convex sides, occasionally subcircular. Ratio of diameter inner body to total spore diameter about $3 / 4$. Wall inner body smooth or scabrate, $1-3 \mu \mathrm{m}$ in thickness. Outer wall with more or less distinct spongeous infrastructure, thickness when measurable $1 \mu \mathrm{m}$. Surface distally and equatorially ornamented, especially around the distal pole, with bacula, clavae and to a minor degree with verrucae, 0.5-(2)-4 $\mu \mathrm{m}$ in height, 0.5-(1)-2 $\mu \mathrm{m}$ in width, concentrated in small groups, $1-10 \mu \mathrm{m}$ apart. Trilete rays distinct, occasionally simple, usually labrate, length $2 / 3-1 / 1$ of inner body radius. Labra thickened, up to $9 \mu \mathrm{m}$ in width, straight, length equal to trilete rays or extending almost to the equator.

Observed dimensions: Total spore diameter in material from Bantry Bay 34-(45)-60 $\mu \mathrm{m}$, in material from Hook Head up to $75 \mu \mathrm{m}$; diameter inner body in Bantry Bay 23-(34)-48 $\mu \mathrm{m}$, up to $60 \mu \mathrm{m}$ in Hook Head.

Remarks: Variant B is differentiated from $C$. decorus variant B by its more subtriangular outline, its thicker ornamentation and its lower ratio of diameter inner body to total spore diameter. Variant B is distinguished from variant A by its larger size and thicker ornamentation.

The variant is highly comparable with the material examined by Turnau (1975) though most specimens have a more subtriangular outline. The 
material from Hook Head exhibits a wider size range but fits completely the description given above.

Within $E$. gradzinskii a transition is found to specimens devoid of baculate or clavate ornamentation via specimens having only one or two of these elements. These latter forms are morphologically transitional between $E$. gradzinskii and Auroraspora macra, A. hyalina and A. asperella.

\section{THE AURORASPORA MACRA MORPHON}

Despite the differences in morphology that can be used in demarcating the above-treated species and variants, one may regularly recognize transitional forms, which are difficult to identify in terms of these units.

Apart from the intraspecific variation in Auroraspora asperella, Colatisporites decorus and Endoculeospora gradzinskii, already expressed in terms of variants, the most conspicuous and commonly occurring transitions can be found between Auroraspora macra, A. hyalina and A. asperella variant B (size; ratio of diameter inner body/total spore diameter). In addition, one may occasionally observe transitions between this $A$. macra-A. hyalina $-A$. asperella complex and $E$. gradzinskii (specimens with a limited number of bacula; Plate VI, 4) as well as $C$. decorus variant A (specimens with grana and a ratio of diameter inner body/total spore diameter between 0.8 and 0.9 ; Plate III, 5). Subcircular baculate forms, showing a high ratio diameter inner body/total spore diameter link $E$. gradzinskii with $C$. decorus variant B (Plate VI, 2). It should be noted, on the other hand, that Auroraspora rectiformis, though closely morphologically related to $A$. macra, $A$. asperella variant $\mathrm{B}$ and $C$. decorus variant $A$ has not yet been linked with these species by means of transitional forms.

The overall morphological relationship of the species under consideration is visualized in Fig.1.

One may recognize a more or less continuous variation linking $A$. macra, A. hyalina, A. asperella, $C$. decorus and E. gradzinskii. Because of this continuous variation, it is here considered that these species could well be regarded to constitute a morphon: "a group of palynological species united by continuous variation of morphological characteristics" (Van der Zwan, 1979).

Common characteristics: (1) Wall inner body smooth or scabrate. (2) Outer wall thin (up to $1.5 \mu \mathrm{m}$ ), with more or less distinct spongeous infrastructure. (3) Trilete rays indistinct or distinct, simple or labrate; length $1 / 2-1 / 1$ of radius inner body.

Variable characteristics: (1) Ratio of diameter inner body/total spore diameter - continuous variation has been observed from ratios of about $2 / 3$ to $9 / 10$ (see Fig.2). (2) Total spore diameter - continuous variation has been observed from $18 \mu \mathrm{m}$ to $80 \mu \mathrm{m}$ (see Fig.2). (3) Overall outline - continuous variation between subtriangular to subcircular forms. (4) Ornamentation continuous variation between smooth, granulate and baculate forms. 
PLATE V
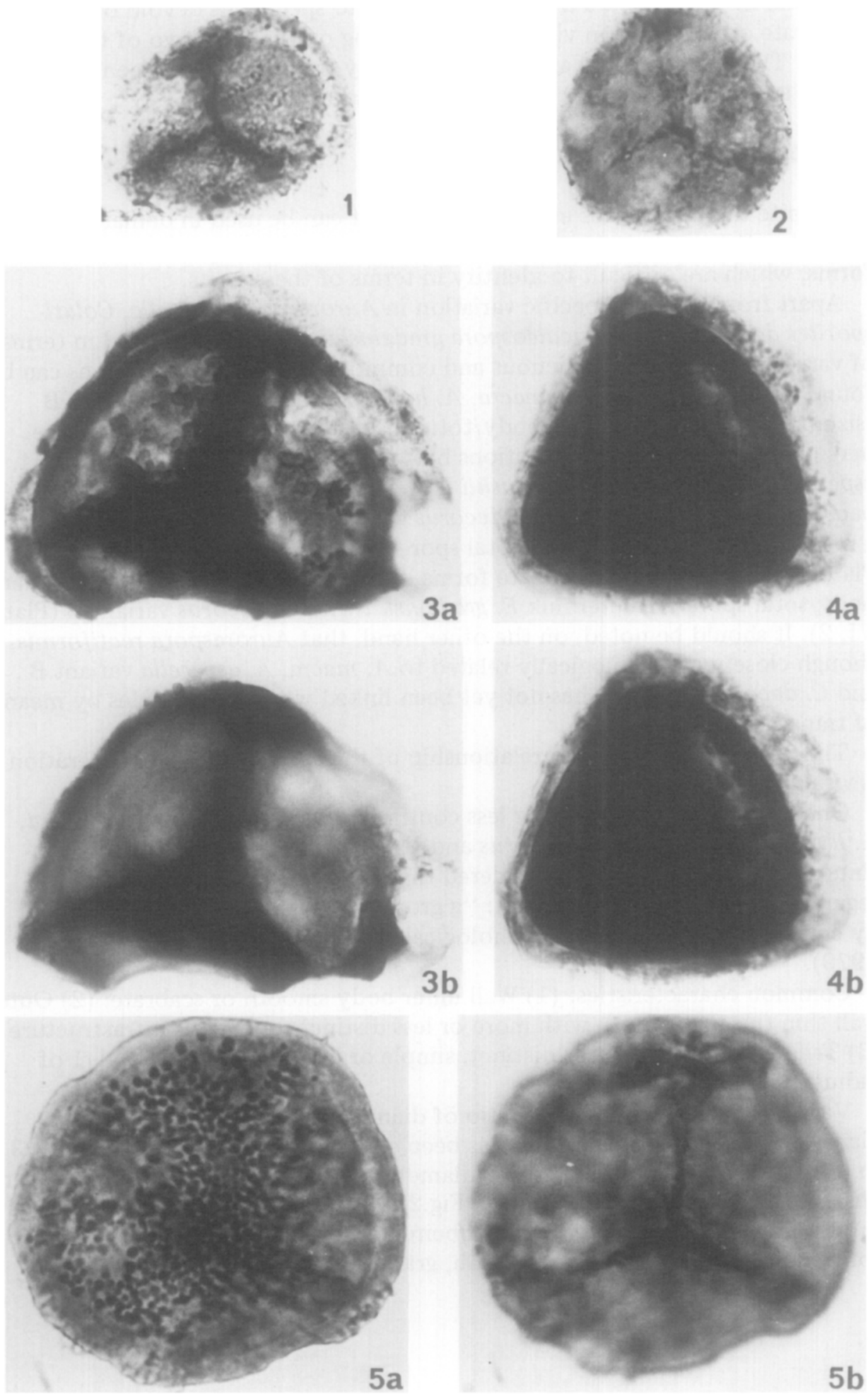


\section{Bantry Bay}

In the Late Devonian-Early Carboniferous transition sequence of Bantry Bay the Auroraspora macra morphon forms an important constituent of the palynological assemblages found (Fig.3). Though not all of the included species and variants are equally significant, quantitative differences may be applied to characterize the successive phases in compositional development of palynological assemblages recognized by Van der Zwan and Van Veen (1978):

(1) The LC, LE and LN phases of the Retispora lepidophyta Assemblage Zone are characterized by $A$. macra and $E$. gradzinskii variant B; additionally represented are $A$. asperella variant $\mathrm{A}, \mathrm{B}$ and $\mathrm{C}$, and $A$. hyalina; $C$. decorus variant $\mathrm{A}$ and $\mathrm{B}$ and $E$. gradzinskii variant $\mathrm{A}$ are absent.

(2) In the LCr phase of the $R$. lepidophyta Assemblage Zone, C. decorus variant $\mathrm{A}$ and $\mathrm{B}$ have their first appearance.

(3) The NR, NDi and NH phases of the Verrucosisporites nitidus Assemblage Zone are characterized by an abundance of $A$. asperella variant $\mathrm{B}$ and C. decorus variant $\mathrm{A}$, and the presence of all the other members of the morphon; in addition it can be said that $A$. asperella variant $\mathrm{A}$ is quantitatively important in the NR phase only; $A$. macra and $E$. gradzinskii variant $\mathrm{B}$ being of minor quantitative importance in this phase.

(4) In the PV phase of the Spelaeotriletes pretiosus Assemblage Zone most of the members of the morphon are more or less equally represented.

The various elements of the $A$. macra morphon can be relatively easily distinguished in assemblages of the phases of the $R$. lepidophyta Assemblage Zone; assemblages from the phases of the $V$. nitidus Assemblage Zone, on the other hand, are characterized by the abundance of a scala of intermediate forms.

Auroraspora rectiformis, closely related but not included in the A. macra morphon, is first recorded in the LN phase and shows irregular occurrences in the succeeding phases.

It should be noted that specimens identified as Auroraspora granulipunctata by Van der Zwan and Van Veen (1978) are now considered to represent C. decorus variant $\mathrm{A}$ and $A$. asperella variant A, B, C.

\section{Hook Head}

For comparison purposes, two characteristic samples from Hook Head have been quantitatively examined for their content of elements of the A. macra morphon:

PLATE V (approx. x 900)

Endoculeospora gradzinskii Turnau 1975

1, 2. Variant A.

3-5. Variant B (3a, b, 4a, b, 5a, b: distal and proximal view). 


\section{PLATE VI}
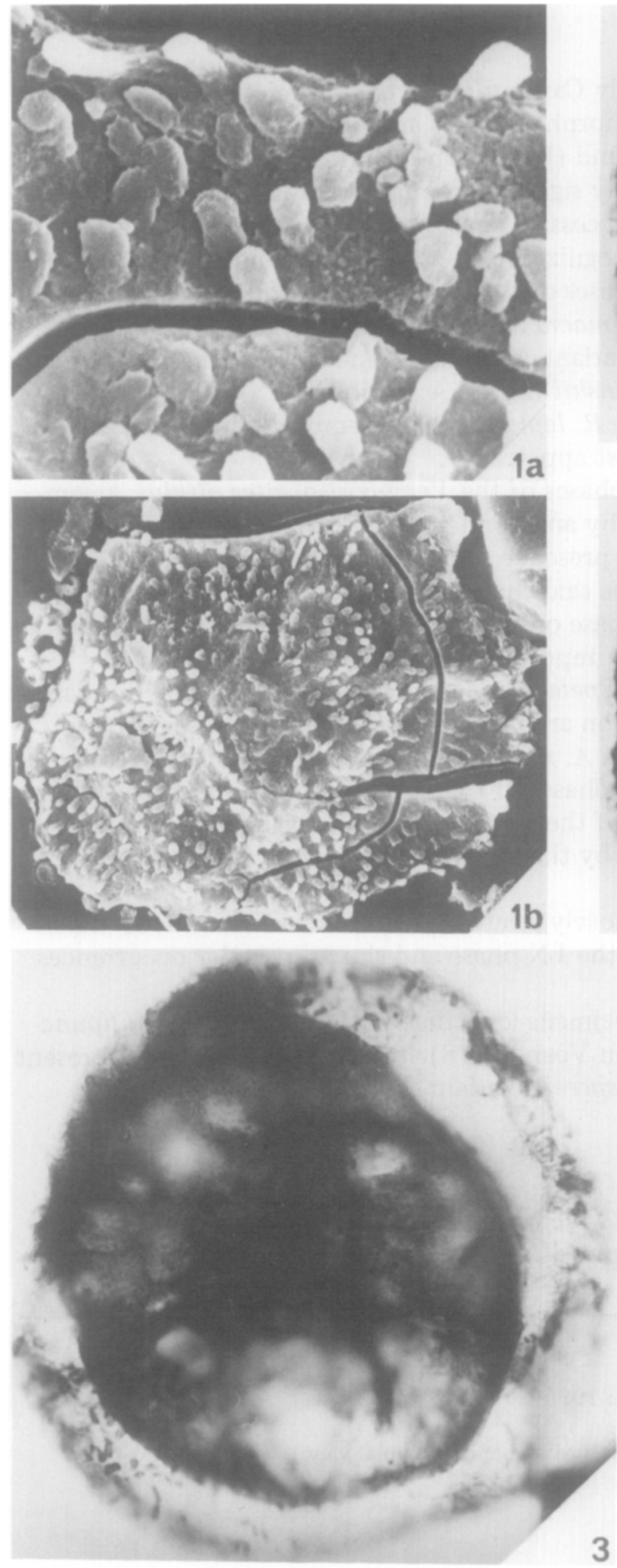
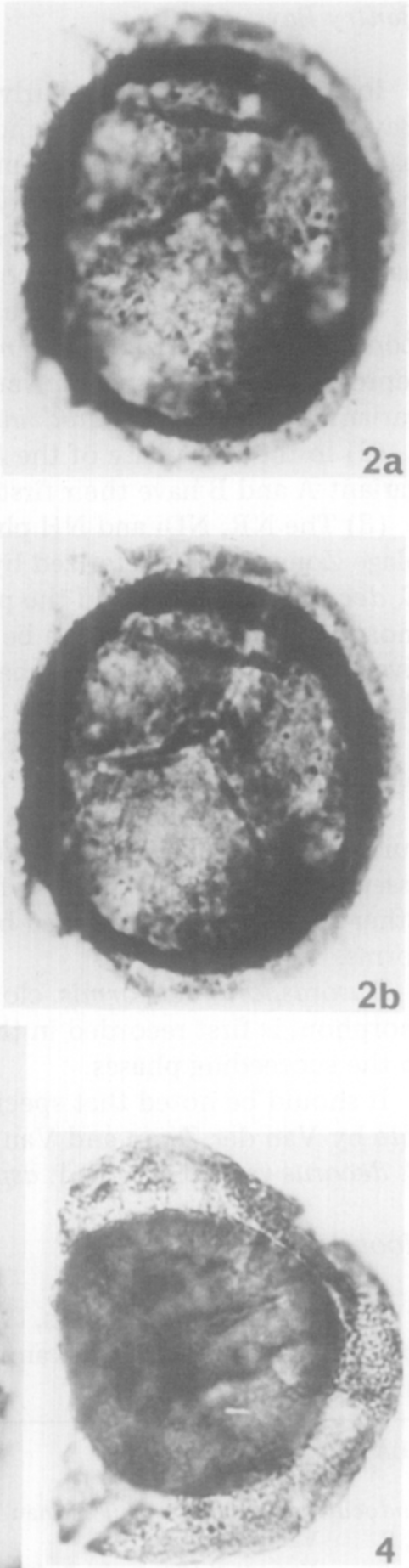


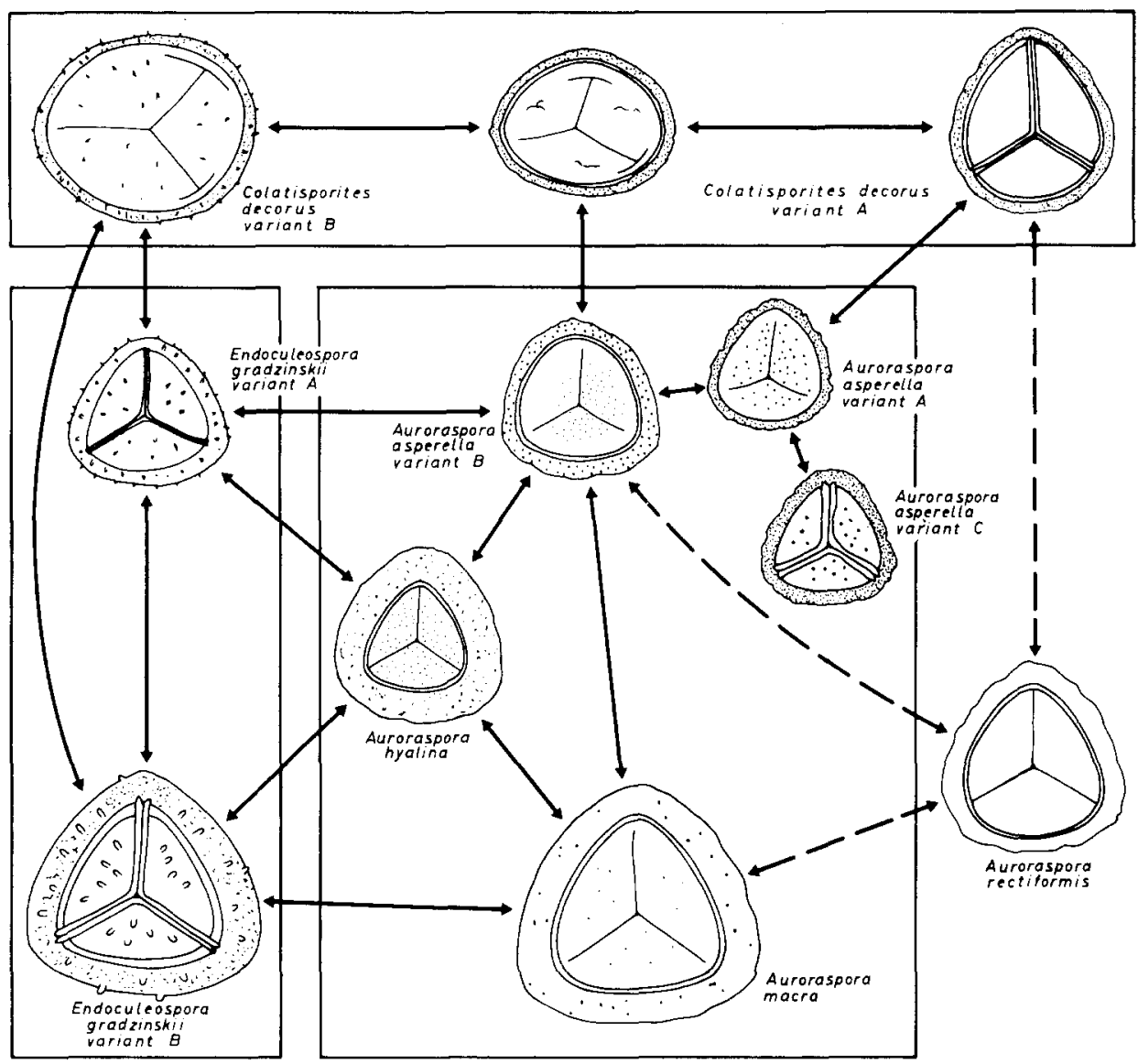

Fig.1. Diagram showing the relationship between the individual members of the A. macra morphon and with $A$. rectiformis.

(1) A sample (H3), attributed to the LE phase, is quantitatively characterized by $A$. asperella variant $\mathrm{A}$ and $\mathrm{B}$, together with $E$. gradzinskii variant $\mathrm{B}$; additionally represented are $A$. hyalina and $A$. macra.

The abundance of $A$. asperella variant $\mathrm{A}$ and $\mathrm{B}$ is in contrast with their rarity in Bantry Bay.

(2) A sample (H7), attributed to the NR phase, is quantitatively characterized by $A$. asperella variant B and C. decorus variant A and B; A. macra,

\section{PLATE VI}

Endoculeospora gradzinskii Turnau 1975

1, 3. Variant B (1: scanning micrographs; a: detail, approx. $\times$ 4000; b: general view, approx. $\times 1000 ; 3$ : large specimen from Hook Head, approx. $\times$ 900).

2. Transitional form to Colatisporites decorus variant $\mathrm{B}(2 \mathrm{a}, \mathrm{b}$ : distal and proximal view, approx. $\times 900$ ).

4. Transitional form to Auroraspora hyalina or to A. macra (approx. $\times$ 900). 


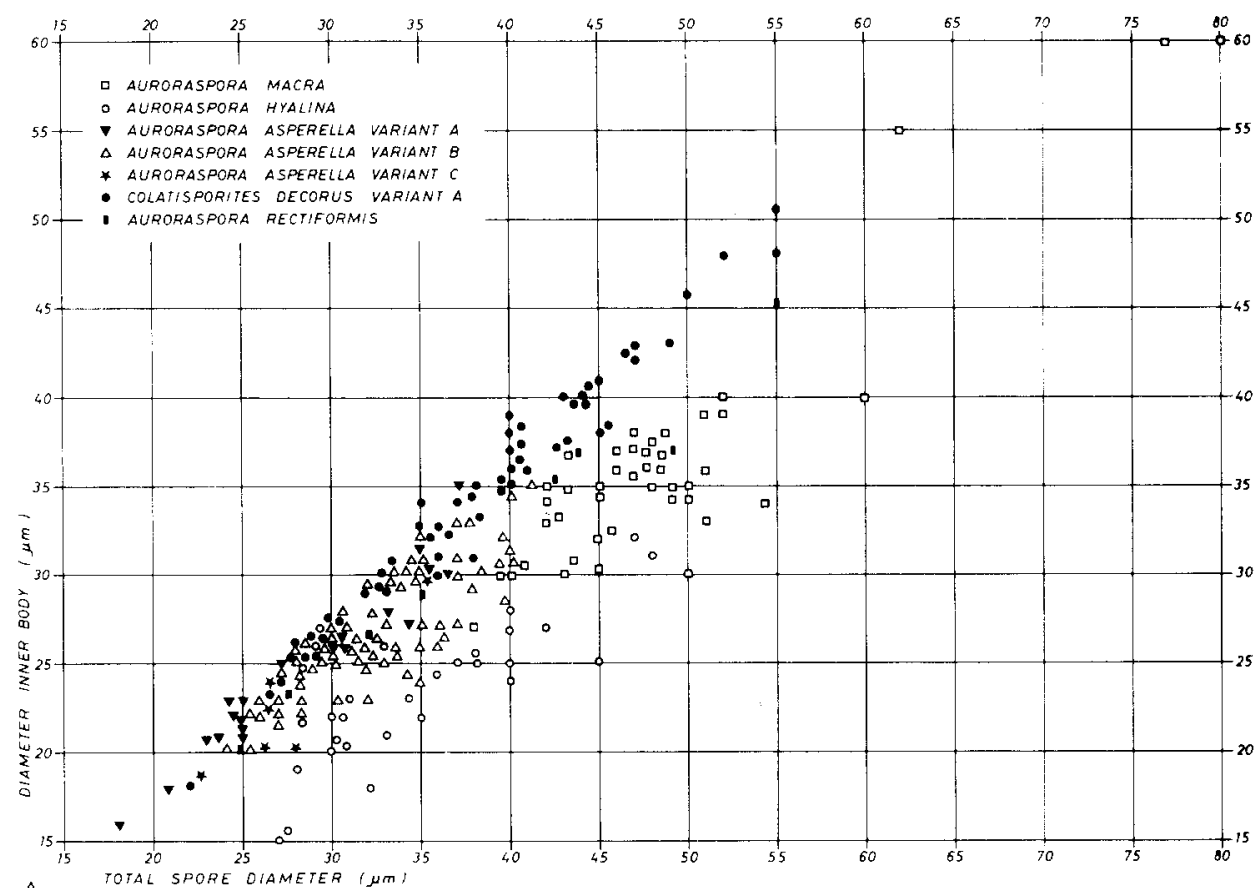

A TOTAL SPORE DIAMETER ( $\mu \mathrm{m})$

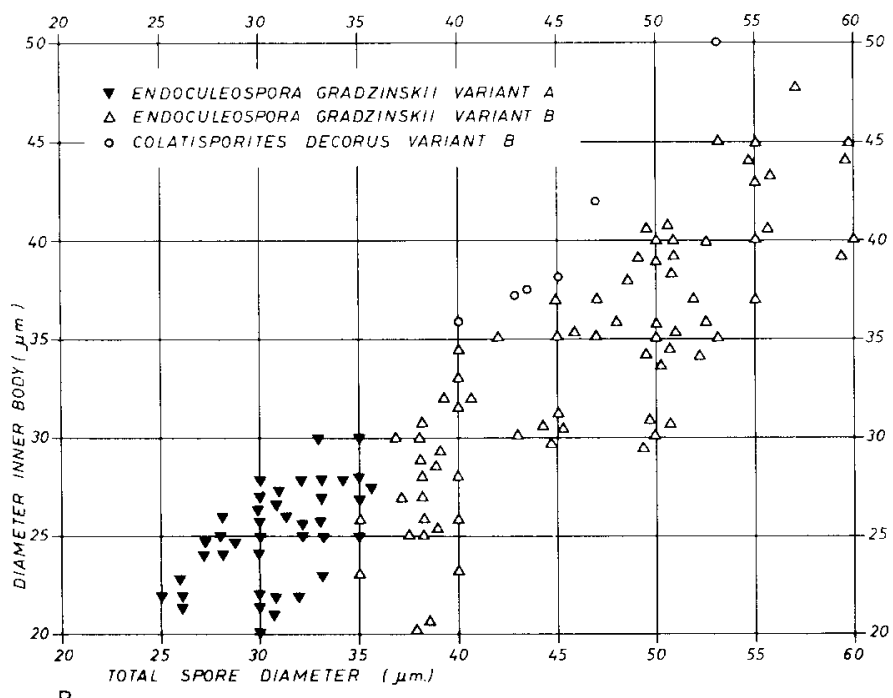

Fig.2. Diagram showing the relationship between the total spore diameter and the diameter inner body: A for A. macra, A. hyalina, A. asperella variant A, B, C, C. decorus variant A and $A$. rectiformis; $\mathrm{B}$ for $E$. gradzinskii variant $\mathrm{A}, \mathrm{B}$ and $C$. decorus variant $\mathrm{B}$. 


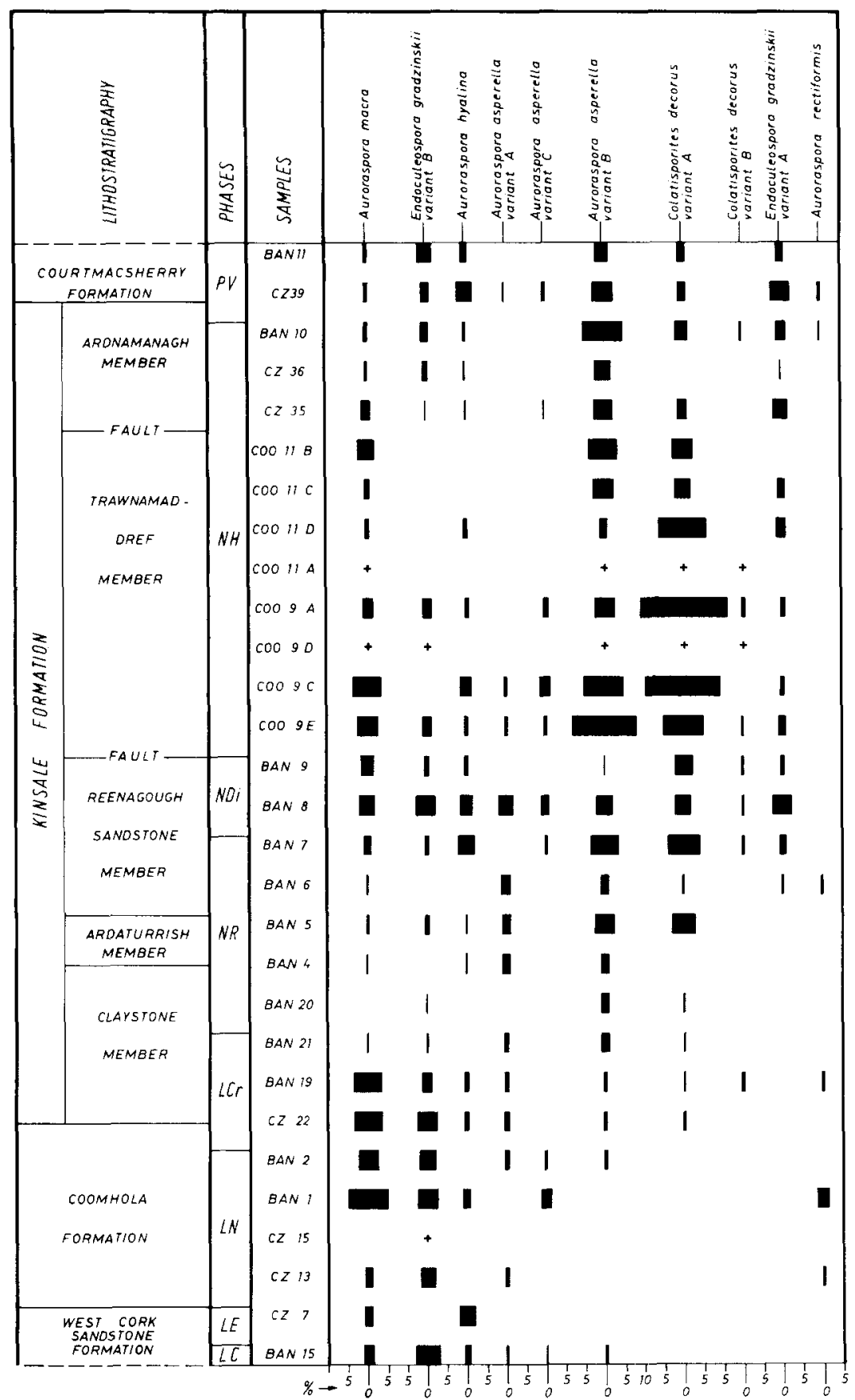

Fig. 3. Quantitative distribution of the A. macra morphon in the Bantry Bay section, S.W. Ireland. + Qualitative record. 
E. gradzinskii variant $\mathrm{A}$ and $\mathrm{B}$ and $A$. asperella variant $\mathrm{A}$ are rather rare. In contrast with Bantry Bay C. decorus variant B is rather important.

\section{Garryvoe}

Qualitative information from Garryvoe also indicates lateral differences. Here, the LE phase is characterized by $A$. macra and $E$. gradzinskii variant $\mathrm{B} ; A$. hyalina, A. asperella and $C$. decorus variant $\mathrm{A}$ are absent. A single specimen of $C$. decorus variant B was found.

The LCr, NR and NH phases are characterized by A. asperella; additionally A. macra and C. decorus variant A and B are represented. E. gradzinskii and A. hyalina were not recorded.

\section{Summary}

Summarizing the stratigraphical distribution of elements of the A. macra morphon so far known from Ireland, we may say that:

(1) The relative frequency of $A$. macra and E. gradzinskii variant B in combination with the general absence of $C$. decorus, characterize the LC, LE and LN phases of the R. lepidophyta Assemblage Zone.

(2) The relative frequency of $A$. asperella variant $\mathrm{B}$ and $C$. decorus variant $A$ and the presence of $E$. gradzinskii variant $\mathrm{A}$ and $C$. decorus variant B characterize the phases of the $V$. nitidus Assemblage Zone and the PV phase of the $S$. pretiosus Assemblage Zone.

(3) The relative frequency of $A$. asperella variant A characterizes the phases of the $R$. lepidophyta Assemblage Zone and the NR phase of the $V$. nitidus Assemblage Zone.

(4) On a regional scale, the quantitative distribution pattern may be different from place to place in assemblages representing the same phase.

\section{DISTRIBUTION ELSEWHERE}

From the literature available it has not been possible to trace Late Devonian-Early Carboniferous assemblages from outside Ireland, in which the complete variation pattern of the $A$. macra morphon could be reconstructed. There are, however, numerous records of most of the individual elements. Of all the species recorded $A$. macra has the greatest geographical distribution. It has been recorded from Great Britain (e.g. Sullivan, 1968; Neves et al., 1973), Belgium (Paproth and Streel, 1970; Endosporites cf. minutus of Combaz and Streel, 1970, Streel, 1966), Denmark (Bertelsen, 1972), Poland (Turnau, 1975, 1978), Iran (Coquel et al., 1977), Australia (Playford, 1971, 1976) and possibly North Africa (Endosporites sp.2947 of Lanzoni and Magloire, 1969). Records vary in age from Late Famennian to Visean.

In Western Europe $A$. hyalina has probably frequently been identified as A. macra. It is recognized as Hymenozonotriletes hyalinus in Russia in beds 
of Famennian to Tournaisian age (e.g. Naumova, 1953; Kedo, 1963).

A. asperella has been recorded from the Famennian and Tournaisian of Russia (Kedo, 1974). When the species identified as Hymenozonotriletes luteolus by Combaz and Streel (1970) and as Perotriletes luteolus by Von Almen (1970) would prove to be conspecific, the area of $A$. asperella would be extended to the upper Famennian and Lower Tournaisian of northern France and North America, respectively.

C. decorus is an important constituent of the Lower Carboniferous of Great Britain (e.g. Neves et al., 1973), Denmark (Bertelsen, 1972) and Spitsbergen (Bharadwaj and Venkatachala, 1961).

E. gradzinskii has been recorded from the Famennian and Tournaisian of Poland (Turnau, 1975, 1978).

\section{CONCLUSIONS}

Summarizing the above-given information, it is evident that the species of the $A$. macra morphon are united by continuous variation. Furthermore it has been demonstrated that in southern Ireland the qualitative and quantitative representation of some individual members of the $A$. macra morphon may be used for regional biostratigraphy. On an interregional scale the assumption of a stratigraphical application may find some support in the restriction of $E$. gradzinskii to the Famennian and Tournaisian and in the restriction of $C$. decorus to the Carboniferous.

Another aspect of the distribution pattern of the individual members of the A. macra morphon is formed by the variation in representation at different localities in southern Ireland. The most striking difference is the variation in quantitative representation between Bantry Bay and Hook Head: (1) the relative abundance of $A$. asperella in the LE phase at Hook Head and its relative rareness at Bantry Bay; (2) the relative abundance of $C$. decorus variant $B$ in the NR phase at Hook Head and its relative rareness at Bantry Bay. Another difference is the absence of A. hyalina in the LE- NH phases and of $E$. gradzinskii from the $\mathrm{LCr}-\mathrm{NH}$ phases of Garryvoe.

In contrast to the earlier described Cyrtospora cristifer morphon (Van der Zwan, 1979), the differences in distribution cannot be related to differences in environment.

The variation in distribution pattern in Ireland may indicate that the A. macra morphon does not reflect an intraspecific morphological variation of spores of a single plant taxon; it seems more likely that each individual member ought to be regarded as a reflection of a separate taxon. Because of the lack of morphological characteristics, however, it is difficult to clearly distinguish separate palynological species.

Consequently, the A. macra morphon is here proposed as a practical, purely morphological, unit in the classification of Late Devonian-Early Carboniferous camerate spores. The morphon can be easily distinguished from coeval camerate spores, such as Hymenozonotriletes commutatus Naumova 1953, Spelaeotriletes resolutus Higgs 1975, etc. 


\section{ACKNOWLEDGEMENTS}

The author wishes to thank Dr. H. Visscher, Utrecht, for his guidance. Grateful acknowledgement is extended to Mr. H. Rijpkema and Mr. H.A. Elsendoorn for drawing the diagrams and for preparing the photomicrographs, respectively.

\section{REFERENCES}

Becker, G., Bless, M.J.M., Streel, M. and Thorez, J., 1974. Palynology and ostracode distribution in the Upper Devonian and basal Dinantian of Belgium and their dependence on sedimentary facies. Meded. Rijks Geol. Dienst, N.S., 25(2): 9-99.

Bertelsen, F., 1972. A Low er Carboniferous microflora from the $\phi$ rslev no.1 borehole, island of Falster, Denmark. Danm. Geol. Unders., II Ser., 99: 1-78.

Bharadwaj, D.C. and Venkatachala, B.S., 1962. Spore assemblage out of a Lower Carboniferous shale from Spitsbergen. Palaeobotanist, 10(1, 2): 18-47.

Caro-Moniez, M., 1962. Sur un niveau à spores du Dévonien supérieur du Sondage de Tournai (Belgique). Soc. Géol. Nord, Ann., 82: 111-115.

Clayton, G., Coquel, R., Doubinger, J., Gueinn, K.J., Loboziak, S., Owens, B. and Streel, M., 1977. Carboniferous Miospores of western Europe; illustration and zonation. Meded. Rijks Geol. Dienst, 29: 1-71.

Combaz, A. and Streel, M., 1970. Microfossiles végétaux du Tournaisien inférieur dans le core drill de Brevillers (Pas de Calais, France). In: Colloque sur la stratigraphie du Carbonifère. Congr. Coll. Univ. Liège, 55: 227-240.

Coquel, R., Loboziak, S., Stampfli, G. and Stampfli-Vuille, B., 1977. Palynology du Dévonien supérieur et du Carbonifère inférieur dans l'Elbruz oriental (Iran nord-est). Rev. Micropaléontol., 20(2): 59-71.

Higgs, K., 1975. Upper Devonian and Lower Carboniferous Miospore assemblages from Hook Head, Co. Wexford. Ireland. Micropaleontology, 21(4): 393-419.

Hoffmeister, W.S., Staplin, F.L. and Malloy, R.E., 1955. Mississippian plant spores from the Hardingsbourgh Formation of Illinois and Kentucky. J. Palaeontol., 29(3): 372399.

Kedo, G.I., 1957. Spores from the supra-salt Devonian deposits of the Pripyat Depression and their stratigraphical significance. Paleontol. Stratigraph. B.S.S.R., 2: $3-43$ (in Russian).

Kedo, G.I., 1963. Spores of the Tournaisian Stage of the Pripyat Depression and their stratigraphical significance. Akad. Nauk B.S.S.R., Inst. Geol. Nauk. Palaeontol. Stratigr. B.S.S.R., (4): 3-131 (in Russian).

Kedo, G.I., 1974. New spore forms from the Upper Devonian of the Pripyat Depression. In: W.K. Golubcov and S.S. Manjkin (Editors), Paleozoic Spores of Byelorussia (Pripyat valley), pp.3-72.

Lanzoni, E. and Magloire, L., 1969. Associations palynologiques et leurs applications stratigraphiques dans le Dévonien supérieur et Carbonifère inférieur du Grand Erg occidental (Sahara Algérien). Inst. Fr. Pét. Rev., 24(4): 441-469.

Naumova, S.N., 1953. Spore-pollen complexes of Upper Devonian of the Russian Platform and their significance for stratigraphy. Trans. Inst. Geol. Sci., Acad. Sci. U.S.S.R., Rel. 143, Geol. Ser., 60: 202 pp (in Russian).

Neves, R., Gueinn, K.J., Clayton, G., Ioannides, N.S. Neville, R.S.W. and Kruszewska, K., 1973. Palynological correlations within the Lower Carboniferous of Scotland and Northern England. R. Soc. Edinb. Trans., 69(2): 23-70. 
Paproth, E. and Streel, M., 1970. Corrélations biostratigraphiques près de la limite Dévonien/Carbonifère entre les faciès littoraux ardennais et les faciès bathyaux rhénans. In: Colloque sur la stratigraphie du Carbonifère. Congr. Coll. Univ. Liège, 55: 365-398.

Playford, G., 1971. Lower Carboniferous spores from the Bonaparte Gulf Basin. Western Australia and Northern Territory. Aust., Bur. Min. Resour., Bull., 115: 1-104.

Playford, G., 1976. Plant microfossils from the Upper Devonian and Lower Carboniferous of the Canning Basin, Western Australia. Palaeontographica, B, 158 (1-4): 1-71.

Richardson, J.B., 1960. Spores from the Middle Old Red Sandstone of Cromarty, Scotland. Palaeontology, 3(1): 45-63.

Richardson, J.B., 1964. Middle Old Red Sandstone spore assemblages from the Orcadian Basin, North-East Scotland. Palaeontology, 7(4): 559-605.

Schemel, M.P., 1950. Carboniferous plant spores from Dagget County, Utah. J. Palaeontol., 24(2): $232-244$.

Staplin, F.L., 1960. Upper Mississippian plant spores from the Golata Formation, Alberta, Canada. Palaeontographica, B 107(1-3): $1-40$.

Streel, M., 1966. Critères palynologiques pour une stratigraphie détaillée du $\operatorname{Tn} 1$ a dans les Bassins Ardenno-Rhénans. Soc. Géol. Belg., Ann., 89(1965-1966), (3): 65-96.

Sullivan, H.J., 1968. A Tournaisian spore flora from the Cementstone Group of Ayreshire, Scotland. Palaeontology, 11(1): 116-131.

Turnau, E., 1975. Microflora of the Famennian and Tournaisian deposits from boreholes of northern Poland. Acta Geol. Polon., 25(4): 505-528.

Turnau, E., 1978. Spore zonation of uppermost Devonian and Lower Carboniferous deposits of western Pomerania (N. Poland). Meded. Rijks Geol. Dienst, 30(1): 1-35.

Van der Zwan, C.J., 1979. Aspects of Late Devonian and Early Carboniferous palynology of southern Ireland. I. The Cyrtospora cristifer morphon. Rev. Palaeobot. Palynol., 28: $1-20$.

Van der Zwan, C.J. and Van Veen, P.M., 1978. The Devonian-Carboniferous transition sequence in southern Ireland: Integration of Palaeogeography and Palynology, Palinología, 1: 469-479.

Von Almen, W., 1970. Miospores from Devonian/Carboniferous boundary, Carter County, Oklahoma, USA. In: Colloque sur la stratigraphie du Carbonifère. Congr. Coll. Univ. Liège, 55: 423-428. 